\title{
Functional evaluation of the lung resection candidate
}

\author{
C.T. Bolliger, A.P. Perruchoud
}

Functional evaluation of the lung resection candidate. C.T. Bolliger, A.P. Perruchoud. (C)ERS Journals Ltd 1998.

ABSTRACT: Advances in operative technique and perioperative care have considerably reduced surgical morbidity and mortality after pulmonary resections. Various single and combined parameters of functional operability have been proposed to assess the surgical risk. Pulmonary function tests adequately assess the pulmonary risk, and baseline or stress electrocardiography, echocardiography and nuclear cardiac studies assess the cardiac risk.

Patients with normal or only slightly impaired pulmonary function (forced expiratory volume in one second (FEV1) and transfer factor of the lung for carbon monoxide $(T \mathrm{~L}, \mathrm{CO}) \geq \mathbf{8 0} \%$ of predicted) and no cardiovascular risk factors can undergo pulmonary resections up to a pneumonectomy without further investigation. For others, exercise testing, pulmonary split-function studies, or a combination of these two methods are recommended. Exercise testing, most frequently performed as a symptom-limited test with the measurement of maximal oxygen uptake $\left(V^{\prime} \mathrm{O}_{2}\right.$, max $)$, assesses both the pulmonary and cardiovascular reserves. A $V^{\prime} \mathrm{O}_{2}$, max of $<10 \mathrm{~mL} \cdot \mathrm{kg}^{-1} \cdot \mathrm{min}^{-1}$ is generally considered prohibitive for any resection, a value of $>20 \mathrm{~mL} \cdot \mathrm{kg}^{-1} \cdot \mathrm{min}^{-1}$ or $>75 \%$ of predicted normal, safe for major resections. Split-function studies are radionuclide-based estimations of the predicted postoperative (ppo) values of various parameters. The currently used ppo-parameters are FEV1-ppo, TL,CO-ppo and, most recently, $V^{\prime} \mathrm{O}_{2}$,max-ppo. Suggested cutoff values for safe resection are: for FEV1-ppo and $T$ L,CO-ppo $\geq 40 \%$ pred; and for $V^{\prime} \mathrm{O}_{2}$, max $\geq 35 \%$ pred, combined with an absolute value of $\geq 10 \mathrm{~mL} \cdot \mathrm{kg}^{-1} \cdot \mathrm{min}^{-1}$. The lowest acceptable ppo-values will still have to be established by additional prospective studies.

In the long-term, resections involving not more than one lobe usually lead to an early functional deficit followed by later recovery. The permanent functional loss in pulmonary function is small $(\leq \mathbf{1 0 \%})$ and exercise capacity is only slightly reduced or not at all. Pneumonectomy, on the other hand, leads to an early permanent loss of about $33 \%$ in pulmonary function and $20 \%$ in exercise capacity. Thus, pulmonary function tests alone overestimate the functional loss after lung resection.

Eur Respir J 1998; 11: 198-212.
Division of Pneumology, University Clinic, Basel, Switzerland.

Correspondence: C.T. Bolliger

Division of Pneumology

University Hospital

Petersgraben 4

4031 Basel

Switzerland

Keywords: Exercise testing

lung resection

morbidity

mortality

preoperative evaluation

postoperative predicted function

pulmonary function

Fax: 0041612654587

Received: December 31996

Accepted after revision June 211997

This work was supported by grants from the Swiss Society of Pneumology and the Foundation for Pneumology, Basel, Switzerland.
The dramatic increase in the incidence of bronchogenic carcinoma has made this disease the most frequent malignancy worldwide. In industrialized nations, the majority of lung resection candidates suffer from bronchogenic carcinoma, whereas only some decades ago benign conditions, such as destroyed lung parenchyma after tuberculosis, had to be removed. The prognosis of bronchogenic carcinoma remains sombre as about $75-85 \%$ are inoperable at the time of diagnosis [1], and despite recent advances in chemo- and radiotherapy regimens, surgical resection remains the only curative form of treatment [2].

Depending on their extent, pulmonary resections lead to permanent loss of pulmonary function. In healthy people, resections up to a pneumonectomy are tolerated remarkably well. Lung cancer patients, however, are mainly smokers or exsmokers who suffer not only from their neoplasm, which should be resected, but also from varying degrees of chronic obstructive pulmonary disease (COPD) or ischaemic heart disease. This puts them at increased risk for postoperative complications and permanent respiratory disability. Apart from the stage and histology of the tumour, the cardiopulmonary reserves, thus, play an important role in the assessment of the surgical risk in lung cancer patients. As recently discussed by BECHARD [3], two critical issues have to be addressed in this context: the ability of the patient to survive the physical stress of the operation itself (i.e. operability) and the amount of lung tissue that can be removed without making the patient a "pulmonary cripple" (i.e. resectability). The term "resectability", as described by BECHARD [3], is used as a functional entity in this article, whereas it usually stands for the anatomical resectability of a tumour. Many single and combined parameters have been used to assess the functional reserves prior to pulmonary resection.

Apart from pulmonary function tests (forced expiratory volume in one second (FEV1), forced vital capacity (FVC), FEV1/FVC), the transfer factor of the lung for carbon monoxide $(T \mathrm{~L}, \mathrm{CO})$ the carbon monoxide transfer 
coefficient $(K \mathrm{CO})$ and the measurement of pulmonary haemodynamics (pulmonary artery pressure, pulmonary vascular resistance) have traditionally been used in the past. Exercise testing has become increasingly popular since a report by EUGENE et al. [4] in 1982, who found that the maximal oxygen uptake $\left(V^{\prime} \mathrm{O}_{2}\right.$, max $)$ during symptom-limited exercise was a much better predictor of operative mortality than tests of ventilatory mechanics (FEV1 and FEV1/FVC). When analysing the literature on functional evaluation of lung resection candidates, one must keep in mind that, since the early reports in the 1950s $[5,6]$, extensive development has taken place; modern anaesthetic techniques, readily available intensive care unit (ICU) facilities, and, more recently, minimally invasive surgical procedures allow pulmonary resections in patients who would have been deemed in-operable some years ago.

In this overview, we would like to discuss the development and the current state of the art of the preoperative functional evaluation before lung resection, with emphasis on the most important tests. It is of utmost importance to measure all functional parameters when the patient is at his or her best. Quite often, pulmonary function and exercise capacity can be improved with an intensive course of antiobstructive therapy, which necessitates postponement or repeat assessment of the functional measurements.

\section{Pulmonary function tests (PFTs)}

\section{Spirometry}

Various lung function parameters have been recommended. As early as 1955, GAENSLER et al. [6] suggested the use of the vital capacity (VC), which should be $>2$ $\mathrm{L}$ before pulmonary resection, without mentioning the extent. Although other authors have also reported the use of the VC, either in absolute values [7] or in percentage of predicted normal values [8-13], it has practically been abandoned in favour of the FEV1.

Early recommendations of FEV1 values for safe resections were $>2 \mathrm{~L}$ for pneumonectomy by Boushy et al. [14] and $>1.5 \mathrm{~L}$ for lobectomy by WERNLY et al. [15]. LODDENKEMPER et al. [16] suggested clearly more conservative values of $>2.5 \mathrm{~L}$ for a pneumonectomy, $>1.75 \mathrm{~L}$ for lobectomy, and $>1.5 \mathrm{~L}$ for segmentectomy. WERNLY et al. [15] also suggested an FEV1 $>2$ L for pneumonectomy, with the rationale that with a $50 \%$ leftright functional distribution the postresectional FEV1 would be $1 \mathrm{~L}$, which they deemed to be the lower limit for adequate pulmonary reserve. In a recent paper by MiLLER [17], reporting on 2,340 patients, the suggested FEV1 values were $>2 \mathrm{~L}$ for pneumonectomy, $>1 \mathrm{~L}$ for lobectomy, and $>0.6 \mathrm{~L}$ for wedge or segmental resections. Three reports used the FEV1 in percentage predicted: MitTman [18] suggesting $>70 \%$, NAGASAKi et al. [19] and, most recently, PATE et al. [20], >40\%; however, none of the three studies mentioned the extent of resection possible with these values. PATE et al. [20] suggested $>1.6 \mathrm{~L}$ for absolute FEV1 values. The recent emphasis on predicted postoperative (ppo) values for FEV1 (FEV1-ppo) will be discussed in the split-function section.
Other parameters, such as the maximal voluntary ventilation [6], peak flow [21], and maximal midexpiratory flow (MEF50) [10, 22], have not been widely use. Static lung volumes measured by helium diffusion or body plethysmography have been suggested to appreciate the extent of overinflation as a potential risk factor. Recommendations for the residual volume (RV) vary, SCHAEFER et al. [23] recommending $<2 \mathrm{~L}$ and BAGG et al. [24] $<2.5$ L. For the ratio between RV and total lung capacity (TLC) (RV/TLC), recommendations are $<40 \%$ $[25,26]$ and $<50 \%[18,27-29]$ The plethysmographically determined airway resistance for a pneumonectomy should be $<0.5-0.8 \mathrm{kPa}\left(<5-8 \mathrm{mbar} \cdot \mathrm{L}^{-1} \cdot \mathrm{s}\right)$ according to certain authors $[13,26,30,31]$. All of these measurements of maximal flows, static lung volumes and airway resistance have been abandoned over time.

\section{Transfer factor}

The transfer factor for carbon monoxide $(T \mathrm{~L}, \mathrm{CO})$ measured with the single-breath technique was suggested as early as 1963 by CANDER [32], who considered a value of $<50 \%$ of predicted as a clear contra-indication for pulmonary resections. NAGASAKI et al. [19] estimated that a $T \mathrm{~L}, \mathrm{CO}$ of $<50 \%$ pred was insufficient for a pneumonectomy, but FERGUSON et al. [33] found a more conservative estimate of $<60 \%$ pred insufficient for "major pulmonary resections". Only recently, Markos et al. [34] brought in the concept of the predicted postoperative TL,CO which will be discussed in the split-function section.

\section{Blood gas measurements}

Arterial blood gas measurements have been part of the routine preoperative evaluation for a long time. However, their predictive value for functional operability is less than certain. For the arterial oxygen tension $\left(\mathrm{Pa}, \mathrm{O}_{2}\right)$ some authors estimate a value of $<6.7 \mathrm{kPa}(50$ $\mathrm{mmHg}$ ) as a clearly increased risk $[31,35]$. For NAGASAKI et al. [19] a value of $<8.0 \mathrm{kPa}(60 \mathrm{mmHg})$ was associated with a high risk for pulmonary resections, and for OLSEN et al. [28] a value of $<6.0 \mathrm{kPa}(45 \mathrm{mmHg})$ on moderate exercise with simultaneous balloon occlusion of the pulmonary artery of the lung to be resected.

More importance has been attached to the arterial carbon dioxide tension $\left(\mathrm{Pa}_{\mathrm{a}} \mathrm{CO}_{2}\right)$, where considerable agreement exists that a raised value of $>6.0 \mathrm{kPa}(45 \mathrm{mmHg})$ represents a high risk for pulmonary resections $[8,31$, 36-39], This value was also mentioned in a recent statement by the American College of Chest Physicians [40]. For NAGASAKI et al. [19], only values exceeding $6.7 \mathrm{kPa}$ $(50 \mathrm{mmHg})$ represented high risk. On the other hand, in a prospective study, recently published by KEARNEY et al. [41], a $P \mathrm{a}, \mathrm{CO}_{2}$ of $>6.0 \mathrm{kPa}(45 \mathrm{mmHg})$ was not a risk factor for postoperative complications. Similarly, Morice et al. [39] found that in high-risk patients a good exercise capacity allowed safe lobectomy in patients with a $P$ a, $\mathrm{CO}_{2}$ value of $>6.0 \mathrm{kPa}(45 \mathrm{mmHg})$. At our institution, Bolliger et al. [42] were able to confirm the findings of MoRICE et al. [39] in a series of five patients of comparable high risk. All five patients had 
Table 1. - Historical synopsis of various single criteria of operability (extent of possible resection indicated where specified)

\begin{tabular}{|c|c|c|c|}
\hline \multicolumn{2}{|l|}{ Parameter } & $\begin{array}{l}\text { Extent of } \\
\text { resection }\end{array}$ & [Ref.] \\
\hline \multicolumn{4}{|l|}{ Spirometry } \\
\hline \multirow[t]{2}{*}{$\mathrm{VC}$} & $\geq 50 \%$ & Lobec & [13] \\
\hline & $\geq 80 \%$ & Pneum & [13] \\
\hline VC-ppo & $>40 \%$ & & [43] \\
\hline \multirow[t]{2}{*}{ FEV 1} & $>1.5 \mathrm{~L}$ & Lobec & [15] \\
\hline & $>2.0 \mathrm{~L}$ & Pneum & {$[14,15]$} \\
\hline FEV $1 \%$ pred & $>40 \%$ & & {$[19,20]$} \\
\hline MVV & $>50 \%$ & & [6] \\
\hline RV/TLC & $<50 \%$ & & {$[18,27-29]$} \\
\hline \multirow[t]{5}{*}{ FEV1-ppo } & $>700 \mathrm{~mL}$ & & [20] \\
\hline & $>800 \mathrm{~mL}$ & & [28] \\
\hline & $>1000 \mathrm{~mL}$ & & {$[15,44]$} \\
\hline & $>30 \%$ & & {$[34,45]$} \\
\hline & $>40 \%$ & & {$[34,46]$} \\
\hline PPP & $>1650$ & & [47] \\
\hline \multicolumn{4}{|c|}{ Transfer factor } \\
\hline \multirow{2}{*}{$T \mathrm{~L}, \mathrm{CO}$} & $>50 \%$ & & {$[19,32]$} \\
\hline & $>60 \%$ & & [33] \\
\hline TL,CO-ppo & $>40 \%$ & & {$[34,48]$} \\
\hline PPP & $>1650$ & & [47] \\
\hline \multicolumn{4}{|c|}{ Arterial blood gas measurements } \\
\hline $\mathrm{Pa}_{\mathrm{a}, \mathrm{O}_{2}}$ & $\begin{array}{l}>6.7 \mathrm{kPa}(50 \mathrm{mmHg}) \\
\text { rest or on exercise }\end{array}$ & & {$[31,35]$} \\
\hline$P \mathrm{a}, \mathrm{CO}_{2}$ & $\begin{array}{l}<6.0 \mathrm{kPa}(45 \mathrm{mmHg}) \\
\text { rest or on exercise }\end{array}$ & & {$[8,31,36-39]$} \\
\hline \multicolumn{4}{|c|}{ Cardiovascular } \\
\hline \multicolumn{4}{|l|}{ No ECG } \\
\hline \multirow[t]{5}{*}{$P$ pa } & $<35 \mathrm{mmHg}$ on & & {$[28,45]$} \\
\hline & TUPAO/50 W & & \\
\hline & $\begin{array}{l}<40 \mathrm{mmHg} \text { on } \\
40-50 \mathrm{~W}\end{array}$ & Lobec & [54] \\
\hline & $\begin{array}{l}<35 \mathrm{mmHg} \text { on } \\
40-50 \mathrm{~W}\end{array}$ & Pneum & [54] \\
\hline & $\begin{array}{l}<30 \mathrm{mmHg} \text { on } \\
40-50 \mathrm{~W}\end{array}$ & Pneum & [55] \\
\hline PVR & $\begin{array}{l}<190 \mathrm{dyn} \cdot \mathrm{s} \cdot \mathrm{cm}^{-5} \text { at res } \\
\text { or on exercise }\end{array}$ & & [56] \\
\hline \multicolumn{4}{|c|}{ Cardiopulmonary } \\
\hline \multirow[t]{7}{*}{$V^{\prime} \mathrm{O}_{2}, \max$} & $>1000 \mathrm{~mL}$ & & [4] \\
\hline & $>20 \mathrm{~mL} \cdot \mathrm{kg}^{-1} \cdot \mathrm{min}^{-1}$ & Pneum & {$[57,58]$} \\
\hline & $\geq 15 \mathrm{~mL} \cdot \mathrm{kg}^{-1} \cdot \mathrm{min}^{-1}$ & Lobec & [39] \\
\hline & $\geq 10 \mathrm{~mL} \cdot \mathrm{kg}^{-1} \cdot \mathrm{min}^{-1}$ & & [58] \\
\hline & $>75 \%$ & Pneum & [59] \\
\hline & $\geq 50 \%$ & & [60] \\
\hline & $\geq 40 \%$ & Lobec & [59] \\
\hline \multirow{2}{*}{$V^{\prime} \mathrm{O}_{2}$, max-ppo } & $\geq 40 \%$ & & [48] \\
\hline & $\geq 10 \mathrm{~mL} \cdot \mathrm{kg}^{-1} \cdot \mathrm{min}^{-1}$ & & [48] \\
\hline \multirow[t]{2}{*}{ Stair climb } & 5 flights & Pneum & {$[61,62]$} \\
\hline & 3 flights & Lobec & {$[61,62]$} \\
\hline Walk tests & $6 \mathrm{~min}>1000 \mathrm{ft}$ & & [46] \\
\hline
\end{tabular}

VC: vital capacity; ppo: predicted postoperative; FEV1: forced expiratory volume in one second; $\%$ pred: percentage of predicted value; MVV: maximal voluntary ventilation; $\mathrm{RV}$ : residual volume; TLC: total lung capacity; $\mathrm{Pa}, \mathrm{O}_{2}$ : arterial oxygen tension; $P \mathrm{a}, \mathrm{CO}_{2}$ : arterial carbon dioxide tension; $T \mathrm{~L}, \mathrm{CO}$ : transfer factor of the lung for carbon monoxide; PPP: predicted postoperative product $(\mathrm{FEV} 1-\mathrm{ppo} \times \mathrm{TL}, \mathrm{CO}-\mathrm{ppo})$; $P$ pa: mean pulmonary artery pressure, TUPAO: temporary unilateral occlusion of the pulmonary artery; PVR: pulmonary vascular resistance; $V^{\prime} \mathrm{O}_{2}$,max: maximal oxygen uptake on exercise; ECG: electrocardiograph; Pneum: pneumonectomy; Lobec: lobectomy. good exercise capacity ( $V^{\prime} \mathrm{O}_{2}$, $\max \geq 69 \%$ pred), although in three of the five the $P \mathrm{a}, \mathrm{CO}_{2}$ was $>6.0 \mathrm{kPa}(45 \mathrm{mmHg})$ at rest with a further increase on exercise. Overall, there is agreement that the determination of arterial blood gas values, primarily the $\mathrm{Pa}_{\mathrm{a}} \mathrm{CO}_{2}$ as a parameter of alveolar ventilation, is useful, and that the old established cutoff values are markers for increased operative risk, but should not in themselves exclude patients from surgery (table 1).

Age

Increasing age is associated with complications after pulmonary resections. In 1955, KROSNIK and WASSERMAN [63] found postoperative arrhythmias after thoracotomies, which were accentuated in the elderly. BATES [64] found a high mortality in patients $>70$ yrs of age after pneumonectomy but not after lobectomy. Various other authors have confirmed that the age limit of 70 yrs represented an independent risk factor for lung resections [19, $49,50]$. On the other hand, reports by KIRSH et al. [65], BREYER et al. [66] and BERGGREN et al. [67], looking more specifically at elderly patients, came to the conclusion that in malignant disease, in particular, pulmonary resections were beneficial. In a study of 100 patients $>65$ yrs old, GERSON et al. [68] found that those with good exercise capacity did not suffer postoperative complications. Based on the majority of reports, age $>70$ yrs represents an independent risk factor for lung resection, but this increased risk is mainly due to co-morbidity in this age group. Elderly patients in a good state of health do not have increased postoperative complications and should not be excluded from surgery solely on the basis of their age [69].

\section{Pulmonary haemodynamics}

Early investigators found that after major pulmonary resection, exercise capacity was decreased due to a reduced maximal cardiac output [70]. It was thought that the marked reduction of the pulmonary vascular bed led to pulmonary artery hypertension and subsequently to right heart failure. Therefore, certain investigators assessed preoperative right ventricular and pulmonary vascular reserve with the use of temporary unilateral occlusion of the pulmonary artery (TUPAO). With this technique, the pulmonary artery pressure $(\mathrm{Ppa})$ and the $\mathrm{Pa}, \mathrm{O}_{2}$ at rest and during exercise were measured while the pulmonary artery of the lung to be resected was occluded by a balloon-tipped catheter. Various authors found that an increased $P$ pa on TUPAO was associated with increased operative risk [32, 51, 71]. UGGLA [9] found a fall in the $P \mathrm{a}, \mathrm{O}_{2}$ on TUPAO and exercise to be the best risk predictor. Patients with a $P$ pa of $\geq 35 \mathrm{mmHg}$ on TUPAO and exercise combined with arterial hypoxaemia $\left(\mathrm{Pa}, \mathrm{O}_{2}\right.$ $<6.0 \mathrm{kPa}(45 \mathrm{mmHg})$ ) were generally deemed to be functionally inoperable by OLSEN and co-workers [28, 45]. Due to its invasiveness, a high failure rate and complications TUPAO has been totally abandoned.

However, $P$ pa measurements at rest and on usually moderate exercise (40-50 W steady-state) without TUPAO are still used. KELLER et al. [55] found that patients with a preoperative $P$ pa $>30 \mathrm{mmHg}$ on $40 \mathrm{~W}$ steady-state exercise developed pulmonary artery hypertension (PAH) 
limiting exercise $1 \mathrm{yr}$ after pneumonectomy. TAUBE and KonIETZKo [72], on the other hand, did not find significant PAH 6 months postoperatively, independent of the extent of resection. According to Goerg et al. [54] $P$ pa on moderate exercise should be $<35 \mathrm{mmHg}$ for a pneumonectomy and $<40 \mathrm{mmHg}$ for a lobectomy. LODDENKEMPER et al. [16] did not find the $P$ pa on exercise predictive up to a value of $45 \mathrm{mmHg}$. Olsen et al. [73] found neither $P$ pa nor the calculated pulmonary vascular resistance (PVR) on submaximal exercise predictive of postoperative complications. The latter finding is in contrast to an early, often cited report by FEE et al. [56], who found a PVR of $<190 \mathrm{dyn} \cdot \mathrm{s} \cdot \mathrm{cm}^{-5}$ at rest or on exercise a criterion of operability (table 1). At our institution, BRÜNDLER et al. [74] reported on 637 patients in whom right heart catheterization was performed. They found a formula incorporating $\mathrm{FEV} 1, T \mathrm{~L}, \mathrm{CO}$ and $\mathrm{Pa}_{\mathrm{a}} \mathrm{O}_{2}$ to predict PAH. Surprisingly, in $276(43 \%)$ of these patients, PAH on moderate exercise was due to left ventricular dysfunction. More recently, the right ventricular ejection fraction was suggested as a further useful parameter for risk prediction [75, 76].

Although these recent investigations show continued interest in pulmonary haemodynamics, the conflicting results and the widely differing cut-off values of $P$ pa make their use questionable. The routine measurement of pulmonary haemodynamics in patients with impaired pulmonary function has, therefore, been abandoned in many institutions in favour of split-function studies and exercise testing.

\section{Cardiac risk}

In comparison to the abundant literature on pulmonary function evaluation before pulmonary resection, the assessment of the cardiac risk in pulmonary resections has received less attention. As early as 1961, MitTMAn [18] showed that an abnormal electrocardiograph (ECG) was associated with an increased risk of suffering an intraoperative or postoperative cardiac event, defined as heart failure, arrhythmias or myocardial infarction. In patients with bronchogenic carcinoma, DidolKar et al. [49] found a postoperative mortality of $9.1 \%$ when the ECG was normal but $21.9 \%$ when it was pathological. The reports of many authors have shown similar findings $[51-53,77,78]$. The multifactorial cardiac risk index published in 1977 by Goldman et al. [50] has since been confirmed by many other reports [79-86]. One of Goldman's risk factors for an operation was a myocardial infarction within the previous 6 months. STEEN et al. [87] found that this risk is especially high with an infarction within the previous 3 months. FOSTER et al. [88] recommended coronary artery bypass surgery before patients with coronary artery disease undergo any other planned surgery. In an interesting study, of 100 patients $>65$ yrs of age before elective abdominal or thoracic surgery, GERSON et al. [68] found that the inability to sustain a cardiac frequency of $>99$ beats $\cdot \mathrm{min}^{-1}$ over 2 min on supine cycle ergometry was more predictive of perioperative complications than radionuclide heart studies.

The problem of postoperative arrhythmias after lung resections was first mentioned by BAILEY and BETTS [89] and CuRRENs et al. [90] in 1943, and has been described by various authors since [63, 90-93]. Prophylactic dig- italization was advocated by many authors in the 1960 s and 1970s [94-96]. However, these early studies were not randomized, and a recent report by RitchiE et al. [97] in a prospective randomized trial found no beneficial effect of perioperative digitalization. The benefit of this practice is, therefore, questionable.

\section{Extent of resection}

There is a clear correlation between the extent of resection and postoperative morbidity and mortality. Segmental or wedge resections have the lowest and pneumonectomies the highest risk $[69,98]$. By international standards, an overall 30 day mortality rate of $\pm 5 \%$ can be considered a very good result. The mortality after pneumonectomy is usually twice or more that after lobectomy. In a large series by LODDENKEMPER [99] comprising 433 patients, the rates were 9.4 and $5.0 \%$, respectively. In the study by MARKos et al. [34] the rates were 16.7 and $0 \%$, respectively. At our own institution, HASSE [100] found rates of 7 and 4\%, respectively, for the years 1972-1978, and recently the figures from 1991-1992, were 10 and $2.2 \%$, respectively [59]. The best results so far were published by Miller [17] in 1993. In his impressive series of 2,340 patients, the overall mortality was $0.64 \%$, for exploratory thoracotomy $0.59 \%$, for wedge resections $0.13 \%$, for lobectomies $0.39 \%$, and for pneumonectomies $4.97 \%$. These excellent results may have been achieved, in part, through fairly rigorous patient selection; as for a pneumonectomy, the FEV1 had to be $>2 \mathrm{~L}$ and FEV1-ppo $>1 \mathrm{~L}$.

The estimation of the amount of lung tissue which can safely be removed is very important in the preoperative evaluation. The development of split-function studies has made it possible to calculate the relative function of the tissue to be removed to the total function of both lungs, and thereby to predict postoperative function.

\section{Split-function studies}

Patients with normal pulmonary function tolerate removal of an entire lung without respiratory problems. In patients with impaired pulmonary function, however, knowledge of the postresectional function is of importance for the assessment of surgical risk. This necessitates the ability to measure the relative contribution of the parenchyma to be resected to the total lung function. The simplest approach is the separate functional analysis of the right and left lung. In 1932, JACOBAEUS et al. [101] introduced bronchospirometry, which was used more extensively after the development of the double-lumen catheter by CARLENS [102] in 1949, which allowed separate analysis of the ventilation of the left and right lung. Various authors [5, 103-107] have used the method, which was invasive (separate intubation of the right and left lung) and has been abandoned in favour of scintigraphic techniques.

Another early test introduced by BERGAN [108] in 1960 was the lateral position test, whereby the relative function of the right and left lung could be determined by changes in the functional residual capacity (FRC) when the patient switched from a supine to a left and right decubital position. The accuracy of this test has 
since been criticized [109-111], and it has also been replaced by scintigraphic investigations.

Radiospirometry with xenon-133 [112] has been used for the regional analysis of ventilation. In the early 1970s, KRISTERSSON et al. [44] were able to accurately predict the functional loss after pneumonectomy and lobectomy [113]. TøNNESEN et al. [114] and subsequently Ali et al. [115] have confirmed these findings, the latter as long as the resection involved more than three segments. Since then, radiospirometry has been replaced by split perfusion scans using intravenous technetium-99 macroaggregate. The breakthrough of this method came with an article by OLSEN et al. [116] in 1974, which reported a good correlation in 13 pneumonectomy patients, between the FEV1-ppo and the value measured 3 months postoperatively. Many authors have since confirmed the feasibility of estimating ventilatory function by perfusion scans, which, because of their general availability and easy performance, have replaced the ventilation studies $[15-17,28,34,48,72,117,118]$. The scintigraphic formula generally used is: FEV1-ppo = preoperative FEV1 $\times(1$ - functional contribution of the parenchyma to be resected).

Only LADURIE and RANSON-BITKER [119] could not find good correlations between the predicted and measured postoperative FEV1 1 yr after pneumonectomy. To this date, there is no consensus on the minimum FEV1-ppo value required for safe resection. OLSEN et al. [28] suggested $800 \mathrm{~mL}$ because of an early publication by SEgAL and ButTerworth [120], who showed that COPD patients with lower values generally had carbon dioxide retention. Other authors $[15,44]$ have suggested a higher value of $1,000 \mathrm{~mL}$, whereas, most recently, PATE et al. [20] found that even $700 \mathrm{~mL}$ based on pneumonectomy was sufficient, as long as the patient could climb at least three flights of stairs or had a maximal oxygen consumption of $>10 \mathrm{~mL} \cdot \mathrm{kg}^{-1} \cdot \mathrm{min}^{-1}$. The value of FEV1-ppo to predict postoperative complications has received increasing attention in recent publications. OLSEN et al. [73] did not find it predictive, whereas KEARNEY et al. [41], in a large prospective study involving 331 patients, found the FEV1-ppo the only independent predictor of postoperative complications.

In the interesting study by MARKos et al. [34] the formula used to estimate FEV1-ppo also proved to be accurate in calculating the predicted postoperative transfer factor (TL,CO-ppo). They found that both a FEV1-ppo and a $T \mathrm{~L}, \mathrm{CO}-\mathrm{ppo}$ of $<40 \%$ pred were good predictors for postoperative complications, but not baseline pulmonary function. They suggested that an FEV1-ppo of $<30 \%$ pred as well as the combination of an FEV1-ppo with a TL,CO-ppo of $<35 \%$ pred represented inoperability. The approach of MARKos et al. [34] to use percentage of predicted rather than absolute values is probably superior to arbitrary absolute values. This might be especially important in the light of the increasing number of females with bronchogenic carcinoma, who should not be denied surgery on the grounds of values established mainly in males. In a small study of 16 patients, HoLDEN et al. [46] found neither FEV1-ppo nor TL,COppo predictive of complications, but all five patients who died within 90 days of surgery had an FEV1-ppo $<40 \%$ pred. On the other hand, the TL,CO-ppo in all nonsurvivors was $>40 \%$ pred. PIERCE et al. [47], in 54 patients, looked at the product of FEV1-ppo $\times$ TL,CO-ppo in percentage predicted (predicted postoperative product) and found values of $<1,650$ highly predictive of complications, whereas baseline PFTs were not. In this paper, the predicted postoperative function was scintigraphically estimated in patients with an FEV 1 of $<55 \%$ pred; in the other patients the formula used was: FEV1-ppo $=$ preoperative $\mathrm{FEV} 1 \times(1-\mathrm{y} / 19)($ where $\mathrm{y}$ is the number of segments to be removed and 19 the total number of segments).

This formula obviates the need for a perfusion scan but has the disadvantage of not taking into account the function of the segments to be removed. This might lead to overestimation of functional loss and possibly the denial of surgery to patients with borderline pulmonary function. ZEIHER et al. [121] found this overestimation to be approximately $250 \mathrm{~mL}$ after lobectomy and 500 $\mathrm{mL}$ after pneumonectomy. This aspect was taken into account by NAKAHARA et al. [122], who also estimated the FEV1-ppo nonscintigraphically, but made a distinction between obstructed and normal subsegments; their formula was: FEV1-ppo $=(1-(b-n) /(42-n)) \times$ preoperative FEV1 (where $n$ and $b$ are the number of obstructed subsegments and total subsegments, respectively, of the parenchyma to be resected, and 42 the total number of subsegments). In this study, FEV1-ppo was also predictive of postoperative complications.

A brand new approach to predict postoperative pulmonary function is the use of quantitative computed tomography (CT) of the chest, which was described by Wu et al. [123] in 1994. They found excellent correlations between predicted and postoperatively measured values for FEV1 $(r=0.93)$ and $\mathrm{FVC}(\mathrm{r}=0.86)$ in a group of 38 patients. These results will have to be validated in prospective studies comparing ppo-values estimated by scintigraphy versus quantitive CT. If CT-based calculations should prove to be equivalent or superior to scintigraphic estimations, the former investigation might become obsolete, as many patients undergo CT scanning of the chest anyway as part of their routine preoperative work-up.

In 1987, Corris et al. [124] and, recently, PUENTEMaestu et al. [125], showed that using Olsen's perfusion scan formula they were able to predict postoperative exercise capacity $\left(V^{\prime} \mathrm{O}_{2}\right.$,max-ppo). At our institution, BOLLIGER et al. [48] recently studied a group of 25 patients with impaired pulmonary function using this formula to predict $V^{\prime} \mathrm{O}_{2}$,max-ppo; and very good correlations were found between predicted and measured postoperative values. Furthermore, $V^{\prime} \mathrm{O}_{2}$, max-ppo was significantly lower in patients with postoperative complications $\left(10.6 \pm 3.6\right.$ vs $\left.14.8 \pm 3.5 \mathrm{~mL} \cdot \mathrm{kg}^{-1} \cdot \mathrm{min}^{-1}\right)$, with a value of $<10$ $\mathrm{mL} \cdot \mathrm{kg}^{-1} \cdot \mathrm{min}^{-1}$ being associated with $100 \%$ mortality (three out of three). Baseline pulmonary function, FEV1ppo and TL,CO-ppo were not significantly different between the two groups, but $T \mathrm{~L}, \mathrm{CO}-\mathrm{ppo}$ was significantly lower in the three patients who died than in the 22 survivors. On the other hand, all three variables FEV1-ppo, $T$ L,CO-ppo and $V^{\prime} \mathrm{O}_{2}$, max-ppo were associated with a $50 \%$ mortality (two out of four patients) if their value was $<40 \%$ pred.

Currently, split-function studies for the predicted postoperative function in the evaluation of lung resection candidates are firmly established, especially in patients 
with impaired pulmonary function (table 1 ). The value of the new parameter, $V^{\prime} \mathrm{O}_{2}$, max-ppo, proposed by BoLLIGER et al. [48] warrants prospective evaluation.

\section{Exercise testing}

All parameters discussed so far look at certain specific aspects of a patient's functional reserves. For decades, the desire was to find an overall parameter for the assessment of the cardiopulmonary reserves encompassing all the others. With this concept, exercise testing seems an ideal tool as it looks at the fitness of a patient, which is an equivalent of the cardiopulmonary reserves. During exercise, oxygen consumption, carbon dioxide production and cardiac output all increase, and the level of work achieved reflects how well the lung, the heart and the vasculature interact to deliver oxygen to the tissue. A thoracotomy with pulmonary resection imitates the stress of exercise to a certain extent.

Exercise testing in the preoperative evaluation before pulmonary resection has attracted interest for some time, and many different protocols have been proposed in the past. Basically, they can be grouped according to the effort demanded from the patient. Three different types of exercise intensity are used: minimal achievement, submaximal; and maximal or symptom-limited tests. The bulk of the literature concerns maximal tests, which are more easily standardized than the two other forms (table 1).

\section{Minimal achievement}

With these tests, a minimal effort has to be achieved, such as climbing a certain number of stairs [51] or maintaining a certain workload for a given amount of time [67]. Walking and stair-climbing tests have been used. For the 12 min walking test, BAGG [126] found no difference between patients with and without postoperative ventilatory complications. In 16 patients at increased operative risk (FEV1 $\leq 1.6 \mathrm{~L})$, HoLDEN et al. [46] found a 6 min walking test of $>1,000 \mathrm{ft}$ or $>44$ steps of stairclimbing predictive of successful surgical outcome. Other reports on stair-climbing by OLSEN and co-workers $[61,62]$ indicate that three flights of stairs permit a lobectomy and five flights pneumonectomy. In a recent study by POLLOCK et al. [127], stair-climbing was standardized (height and width of steps, number of steps per floor), and it was concluded that an achievement of 4.6 flights (83 steps) corresponded to a $V^{\prime} \mathrm{O}_{2}$ of 20 $\mathrm{mL} \cdot \mathrm{kg}^{-1} \cdot \mathrm{min}^{-1}$, which is generally considered a safe limit for a pneumonectomy. All these studies have the advantage of being simple and cheap. On the other hand, they generally suffer the disadvantage of poor standardization. For stair-climbing, for example, the speed of ascent is important, and an insufficient number of floors in a hospital could very simply preclude the feasibility of the test. Furthermore, in the available literature, online ECG readings for the assessment of exercise-induced cardiac events, such as arrhythmias or ischaemias, are not usually reported. OLDER et al. [128] showed, in a group of 187 elderly patients undergoing major abdominal surgery, that a low anaerobic threshold $\left(V^{\prime} \mathrm{O}_{2}\right.$, max $<11 \mathrm{~mL} \cdot \mathrm{kg}^{-1} \cdot \mathrm{min}^{-1}$ ) and ischaemia on maximal exercise testing were independent risk factors for perioperative mortality, and the combination of the two resulted in a mortality rate of $42 \%$. In summary, the minimal achievement exercise tests lack standardization and inadequately assess cardiac events. In the absence of cardiopulmonary exercise units, a set-up like the one described by POLLOCK et al. [127] is certainly acceptable provided the patient does not have ischaemic heart disease.

\section{Submaximal tests}

The rationale behind submaximal testing is the better tolerance of the exercise stress in lung resection candidates who are usually elderly, suffer from COPD and might, therefore, not be motivated to perform exercise to exhaustion. MiYoshi et al. [129] (in 1987), NAKAHARA et al. [43] and NAKAgAwA et al. [130] (in 1992), who were all from the same Japanese group, reported on their protocol in which patients with a VC-ppo of $>40 \%$ pred were exercised with a $25 \mathrm{~W}$ increase every 3 min until the cardiac frequency reached 140 beats $\cdot \mathrm{min}^{-1}$ or the respiratory exchange ratio $(\mathrm{R})$ exceeded 1.0. All patients had catheters in the pulmonary and radial arteries. They found that age and resting pulmonary function were predictive of postoperative morbidity but not mortality. Good predictors of mortality were two calculated parameters: the $V^{\prime} \mathrm{O}_{2}$ /body surface area (BSA) and the oxygen delivery $\left(\mathrm{O}_{2} \mathrm{D}\right) / \mathrm{BSA}$ measured at a blood lactate level of $20 \mathrm{mg} \cdot \mathrm{dL}^{-1}$ (LA20), which they termed the "empirical anaerobic threshold". $V^{\prime} \mathrm{O}_{2} / \mathrm{BSALA}_{20}$ should be $>400 \mathrm{~mL} \cdot \mathrm{min}^{-1} \cdot \mathrm{m}^{-2}$ and $\mathrm{O}_{2} \mathrm{D} / \mathrm{BSALA} 20>500 \mathrm{~mL} \cdot \mathrm{min}^{-1} \cdot \mathrm{m}^{-2}$ for thoracotomy. They proposed an algorithm for the preoperative functional evaluation [43] incorporating these parameters together with the VC-ppo, which should be $\geq 40 \%$ pred, and FEV1-ppo, $>30 \%$ pred.

OLSEN et al. [73] studied 29 patients with pulmonary artery catheters on cycle ergometry at workloads of 25 and $40 \mathrm{~W}$ during $2-4 \mathrm{~min}$. The 22 survivors were best separated from the seven nonsurvivors by the cardiac index $\left(5.5 \pm 1.3\right.$ vs $\left.3.9 \pm 0.3 \mathrm{~L} \cdot \mathrm{min}^{-1} \cdot \mathrm{m}^{-2}\right), \mathrm{O}_{2}$ delivery $\left(1,630 \pm 462\right.$ vs $\left.1070 \pm 95 \mathrm{~mL} \cdot \mathrm{min}^{-1} \cdot \mathrm{m}^{-2}\right)$ and calculated $V^{\prime} \mathrm{O}_{2}\left(11.3 \pm 2.1\right.$ vs $\left.7.8 \pm 1.5 \mathrm{~mL} \cdot \mathrm{kg}^{-1} \cdot \mathrm{min}^{-1}\right)$. In a study by PIERCE et al. [131], patients exercised on a bicycle, and the lobe to be resected was occluded through a fibreoptically introduced balloon catheter. If the patient could maintain moderate exercise, he was sent to surgery and progressed well. RAO et al. [132] found that desaturation to $<90 \%$ on pulse oximetry, at rest, while walking on level ground or climbing two flights of stairs identified high-risk lung resection candidates.

Although submaximal exercise protocols are less strenuous than maximal tests, they have the clear disadvantage of being invasive and causing discomfort to the patient. The current trend in exercise testing is, therefore, towards less invasiveness but maximal effort.

\section{Maximal tests}

As early as 1955 , TAYLOR et al. [133] showed $V^{\prime} \mathrm{O}_{2}$, max to be an objective parameter of the cardiorespiratory reserves. Later it was shown, mainly by cardiologists [134-136], that $V^{\prime} \mathrm{O}_{2}$,max was more reproducible than duration of exercise. Most recently, CAHALIN et al. [137] showed the distance ambulated in a 6 min walk test to 
be predictive of $V^{\prime} \mathrm{O}_{2}$, max and short-term event-free survival in patients with advanced heart failure.

Although known of for some time, the assessment of $V^{\prime} \mathrm{O}_{2}$ in lung resection candidates has only gained interest after a report by EUGENE et al. [4] in 1982, who found that 15 out of 19 patients with a $V^{\prime} \mathrm{O}_{2}, \max$ of $>1$ L had no postoperative complications, whereas three out of four patients with $<1 \mathrm{~L}$ died of cardiopulmonary failure. In that study, FEV1 and VC had no predictive value. In the same year, Colman et al. [138] published a study with a larger number of 59 patients, in which $V^{\prime} \mathrm{O}_{2}$,max was not found to be predictive of postoperative complications. This study is continuously cited as a negative study. But it is difficult to compare it to other reports because the definition of complications included surgical parameters, such as excess blood loss, prolonged air leak, empyema, wound infection and gastric haemorrhage, which are not likely to be predictable by exercise testing.

SMith et al. [57], studying 22 patients, did not find baseline pulmonary function or FEV1-ppo predictive of surgical outcome. $V^{\prime} \mathrm{O}_{2}$, max, on the other hand, was significantly higher in patients without than in patients with complications $\left(22.4 \pm 1.4\right.$ vs $\left.14.9 \pm 0.9 \mathrm{~mL} \cdot \mathrm{kg}^{-1} \cdot \mathrm{min}^{-1}\right)$. Of 10 patients with a $V^{\prime} \mathrm{O}_{2}$, max of $>20 \mathrm{~mL} \cdot \mathrm{kg}^{-1} \cdot \mathrm{min}^{-1}$ only one suffered a complication, in contrast to all six patients with a $V^{\prime} \mathrm{O}_{2}$, max of $<15 \mathrm{~mL} \cdot \mathrm{kg}^{-1} \cdot \mathrm{min}^{-1}$. In 1987 , BECHARD and WETSTEIN [58] reported a study with 50 patients confirming the findings of SмITH et al. [57] of a safe upper cut-off value of $20 \mathrm{~mL} \cdot \mathrm{kg}^{-1} \cdot \mathrm{min}^{-1}$ : none of their patients with a $V^{\prime} \mathrm{O}_{2}$, max $>20 \mathrm{~mL} \cdot \mathrm{kg}^{-1} \cdot \mathrm{min}^{-1}$ sustained any complications. On the other hand, five of the seven patients with a $V^{\prime} \mathrm{O}_{2}$, max $<10 \mathrm{~mL} \cdot \mathrm{kg}^{-1} \cdot \mathrm{min}^{-1}$ had complications, including two deaths. The definition of complications was virtually identical to that in the study by SMITH et al. [57].

In the study by Markos et al. [34] mentioned above, $V^{\prime} \mathrm{O}_{2}$,max, either in absolute values $\left(\mathrm{mL} \cdot \mathrm{kg}^{-1} \cdot \mathrm{min}^{-1}\right)$ or expressed as a percentage of predicted, did not discriminate between the presence and the absence of complications. However, in lobectomy patients with complications, $V^{\prime} \mathrm{O}_{2}$, max was significantly lower and a fall in oxygen saturation at exercise $>2 \%$ was also predictive of complications. In the study by Holden et al. [46], $V^{\prime} \mathrm{O}_{2}$, max on cycle ergometry was not a discriminator between patients without or with minor complications and those who died within 90 days of surgery. These results should be interpreted with caution, as seven out of the 16 patients did not exercise to exhaustion, making the remaining nine a very small sample size. Furthermore, postoperative mortality cannot be compared to most other studies, where it is limited to 30 days.

A very valuable study, published by Morice et al. [39] and discussed in a editorial by OLSEN [139], investigated 37 patients with resectable bronchogenic carcinoma, who were at high operative risk because of at least one of the following parameters: FEV $1 \leq 40 \%$ pred; radionuclide calculated FEV1-ppo $\leq 33 \%$ pred; or $\mathrm{Pa}_{\mathrm{a}} \mathrm{CO}_{2}$ $\geq 6.0 \mathrm{kPa}(45 \mathrm{mmHg})$. Eight of these patients underwent lobectomy because their $V^{\prime} \mathrm{O}_{2}$, max was $>15 \mathrm{~mL} \cdot \mathrm{kg}^{-1} \cdot \mathrm{min}^{-1}$. Only two of the eight patients had nonfatal postoperative complications, and all eight were discharged from hospital by day 22. Similar results were reported by PATE et al. [20].
In a small series of five lung cancer patients, BOLLIGER et al. [42] recently confirmed that good exercise capacity, defined as a $V^{\prime} \mathrm{O}_{2}$, max of $\geq 69 \%$ pred on cycle ergometry, allowed safe lobectomy, although all five patients had at least one criterion of high surgical risk (FEV1ppo $<30 \%$ pred, $T$ L,CO $<60 \%$ pred combined with a fall in $\mathrm{Pa}, \mathrm{O}_{2}$ at peak exercise $>0.67 \mathrm{kPa}(5 \mathrm{mmHg})$, and $P$ a, $\left.\mathrm{CO}_{2}>6.0 \mathrm{kPa}(45 \mathrm{mmHg})\right)$.

In 1993, DALES et al. [140] reported on 117 consecutive patients undergoing thoracotomy for possible or definite lung cancer. One hundred and fifteen underwent PFT but only 46 had treadmill exercise testing. The reasons given for not exercising everybody were lack of time or money. Outcome parameters were separated into all complications and respiratory complications only. The definition of all complications included purely surgical problems such as air leak, bronchopleural fistula and haemothorax, as in the study by COLMAN et al. [138]. When the analysis was restricted to respiratory complications only, a twofold or greater risk was associated with current smoking, cancer as the final pathological condition, at least moderate dyspnoea, FEV1 $<60 \%$ pred, ventilatory reserve $<25 \mathrm{~L}$ and a $V^{\prime} \mathrm{O}_{2}$, max $<1.25$ L. The shortcomings of this study are the lack of explanation as to why the reported cut-off values were chosen, and the fact that only $39 \%$ (46 out of 117) patients underwent exercise testing, which could well reflect a selection bias.

EPSTEIN et al. [141] compared preoperative cycle ergometry to a multifactorial cardiopulmonary risk index (CPRI) in 42 lung cancer patients. The definition of postoperative complications was comparable to that in the paper by Sмiтн et al. [57]. There was no difference in $V^{\prime} \mathrm{O}_{2}$, max between the patients with and without complications (16.4 \pm 1.4 vs $\left.16.7 \pm 0.8 \mathrm{~mL} \cdot \mathrm{kg}^{-1} \cdot \mathrm{min}^{-1}\right)$, but based on a threshold value the risk for cardiopulmonary complications was six times greater in those with a $V^{\prime} \mathrm{O}_{2}$, max/BSA of $<500 \mathrm{~mL} \cdot \mathrm{min}^{-1} \cdot \mathrm{m}^{-2}$. The CPRI was found to be superior to $V^{\prime} \mathrm{O}_{2}$, max as a predictor of complications. This CPRI consists of a cardiac part containing the time-honoured criteria established by GoLDMAN et al. [50] with a score of $0-4$. The pulmonary part has a score of $0-6$, one point for each of the following six variables: 1) obesity (body mass index (BMI) $\geq 27 \mathrm{~kg} \cdot \mathrm{m}^{-2}$ ); 2) cigarette smoking within 8 weeks of surgery; 3 ) productive cough within 5 days of surgery; 4) diffuse wheezing within 5 days of surgery; 5) FEV1/FVC $<70 \%$, and 6) a $\mathrm{Pa}_{\mathrm{a}} \mathrm{CO}_{2}$ $>6.0 \mathrm{kPa}(45 \mathrm{mmHg})$. The total CPRI score has, therefore, a range of $1-10$. Patients with a score of $\geq 4$ were 22 times more likely to develop a complication compared to a CPRI $<4$.

In a recent second report, EPSTEIN et al. [142] confirmed the value of the CPRI, but found that the inability to perform bicycle ergometry also independently predicted postoperative complications. The CPRI is an interesting and simple way of obtaining information concerning cardiopulmonary risk factors; nevertheless, the pulmonary part of this CPRI must be addressed critically: criteria 2 to 4 are observer-dependent, and an $\mathrm{FEV} 1 / \mathrm{FVC}$ ratio $<70 \%$ is not a generally accepted parameter of increased operative risk. We therefore think that this CPRI needs further prospective evaluation and that, at this stage, a patient should not be denied surgery solely on the basis of such an index. 
At our institution, Bolliger et al. [59] evaluated a consecutive series of 80 lung resection candidates and found that $V^{\prime} \mathrm{O}_{2}$, max was the best predictor of postoperative complications. A receiver operating characteristic (ROC)-curve analysis proved $V^{\prime} \mathrm{O}_{2}$, max, when expressed as a percentage of predicted, to be significantly more sensitive than when analysed in absolute values $(\mathrm{mL}$. $\left.\mathrm{kg}^{-1} \cdot \mathrm{min}^{-1}\right)$. The estimated probability of suffering no complication was $90 \%$ with a $V^{\prime} \mathrm{O}_{2}$, max of $>75 \%$ pred, and $10 \%$ with a $V^{\prime} \mathrm{O}_{2}$, max of $<43 \%$ pred. A value of $<60 \%$ pred proved to be prohibitive for resections involving more than one lobe. A subgroup of 25 patients with impaired pulmonary function (FEV $1<2 \mathrm{~L}$ or $T \mathrm{~L}, \mathrm{CO}<50 \%$ pred) underwent radionuclide split-function studies [48]. Again, $V^{\prime} \mathrm{O}_{2}$, max both expressed as a percentage of predicted and in absolute values $\left(\mathrm{mL} \cdot \mathrm{kg}^{-1} \cdot \mathrm{min}^{-1}\right)$ discriminated between patients suffering complications and those who did not. FEV1-ppo and TL,CO-ppo were not predictive, but TL,CO-ppo was predictive of fatal complications. In their latest study in high-risk lung resection candidates, MORICE et al. [60] confirmed the usefulness of $V^{\prime} \mathrm{O}_{2}$,max expressed as a percentage of predicted normal values. They found that a $V^{\prime} \mathrm{O}_{2}$, max of $\geq 50 \%$ pred was a better predictor of operability than the absolute value of $\geq 15 \mathrm{~mL} \cdot \mathrm{kg}^{-1} \cdot \mathrm{min}^{-1}$ that they had used previously [39].

\section{Algorithm for the functional evaluation of the lung resection candidate}

Despite the increasing enthusiasm for split-function studies and exercise testing, one has to remember that many lung resection candidates can undergo resections up to a pneumonectomy without any sophisticated tests, which are costly and not universally available. This stresses the need for an algorithm for the preoperative functional evaluation. A modern approach should probably include PFT, ppo-function and exercise variables. In 1992, NAKAHARA et al. [43] reported their approach based on submaximal testing. Criteria of operability are a VC-ppo $\geq 40 \%$ pred, an FEV1-ppo $\geq 30 \%$ pred, $V^{\prime} \mathrm{O}_{2} /$ BSALA20 $\geq 400 \mathrm{~mL} \cdot \mathrm{min}^{-1} \cdot \mathrm{m}^{-2}$, and $\mathrm{O}_{2} \mathrm{D} /$ BSALA20 $\geq 500$ $\mathrm{mL} \cdot \mathrm{min}^{-1} \cdot \mathrm{m}^{-2}$. Similarly, BECHARD [3] recommends FEV 1ppo $\geq 30 \%$ pred, $T$ L,CO-ppo $>40 \%$ pred and a $V^{\prime} \mathrm{O}_{2}$, max $>10 \mathrm{~mL} \cdot \mathrm{kg}^{-1} \cdot \mathrm{min}^{-1}$ as limits of operability.

Based on the bulk of the recent literature and on our own investigations, we favour noninvasive maximal over invasive submaximal exercise testing. In the preoperative functional evaluation, we propose the following algorithm (fig. 1), which was slightly amended after prospective testing in 132 consecutive patients [143]. Adherence to this algorithm resulted in a postoperative complication rate of $11 \%$, with a very low mortality of $1.5 \%$. This meant a $50 \%$ reduction in complications in comparison to our previous series [59].

Patients who have a negative cardiac history (including a normal ECG) and whose FEV1 and TL,CO are both $\geq 80 \%$ pred can undergo lung resection up to a pneumonectomy without any further tests. The cut-off values of $80 \%$ pred were chosen because the respective postoperative values are usually $>40 \%$ pred - identified as safe $[34,47]$ - even after pneumonectomy as the diseased lung rarely contributes $>50 \%$ of the total lung function [144]. Any patient with active or suspected cardiac disease should first undergo a thorough cardiac work-up and, if necessary, even coronary bypass surgery in case of ischaemic heart disease [88]. Only patients whose cardiac condition is amenable to treatment can undergo further investigation for pulmonary resection.

If either FEV1 or TL,CO is $<80 \%$ pred, exercise testing with the measurement of $V^{\prime} \mathrm{O}_{2}$, max is performed. Rarely, exercise testing will pick up ischaemic heart disease in patients with a negative cardiac history and a normal ECG. This will also lead to a cardiac work-up (interrupted line in the algorithm). If $V^{\prime} \mathrm{O}_{2}, \max$ is $>75 \%$ pred or $>20 \mathrm{~mL} \cdot \mathrm{kg}^{-1} \cdot \mathrm{min}^{-1}$, patients qualify for resection up to a pneumonectomy; if it is $<40 \%$ pred or 10 $\mathrm{mL} \cdot \mathrm{kg}^{-1} \cdot \mathrm{min}^{-1}$ they are inoperable. All patients with $V^{\prime} \mathrm{O}_{2}$, max values in between undergo split-function studies with the aid of a pulmonary perfusion scan to determine their predicted postoperative function (ppo-function). Firstly, FEV1-ppo and TL,CO-ppo are analysed; if the values for both parameters are $<40 \%$ pred, patients are deemed inoperable. If either one is $\geq 40 \%$ pred, then $V^{\prime} \mathrm{O}_{2}$, max-ppo becomes the decisive factor. With a $V^{\prime} \mathrm{O}_{2}$, maxppo of either $<35 \%$ pred or $<10 \mathrm{~mL} \cdot \mathrm{kg}^{-1} \cdot \mathrm{min}^{-1}$ patients are also deemed inoperable; whereas patients with a $V^{\prime} \mathrm{O}_{2}$, max-ppo $\geq 35 \%$ pred and $\geq 10 \mathrm{~mL} \cdot \mathrm{kg}^{-1} \cdot \mathrm{min}^{-1}$ are operable up to the extent which was used for the prediction of postoperative function. This algorithm integrates the functional parameters of operability and their respective cut-off values from the most recent literature.

The difference between our approach and those suggested by NaKAHARA et al. [43] and BeCHARD [3] is that we perform exercise testing before split-function studies as we found it superior to them. In any case, both tests are complementary and their combined use allows excellent assessment of the surgical risk.

\section{Effect of lung resection on postoperative pul- monary function and exercise capacity}

Most of the above-mentioned tests have been used to assess operability and resectability in patients with impaired pulmonary function. The studies available indicate that a patient with an estimated FEV1-ppo of $>700-1,000 \mathrm{~mL}$ or $30 \%$ pred will survive the operation, be discharged from hospital, and actually have the predicted postoperative FEV1, which will be enough to avoid pulmonary incapacity. For patients with normal or only slightly abnormal pulmonary function, however, a lung resection up to a pneumonectomy is clearly feasible without split-function or exercise studies.

The relevant question for many lung resection candidates is, therefore, not whether they will tolerate pulmonary resection but rather whether they can lead a normal life as before, both in their private as well as in their professional environment. The answer depends mainly on the extent of resection. Various studies have looked at the functional loss after lung resection in terms of pulmonary function $[16,44,113,115-117$, 145-147]. Ali et al. [115] and LODDENKEMPER et al. [16] have shown that resections involving not more than one lobe lead to an early loss in pulmonary function with later recovery and little permanent deficit. As for the preoperative assessment, exercise capacity reflects the 


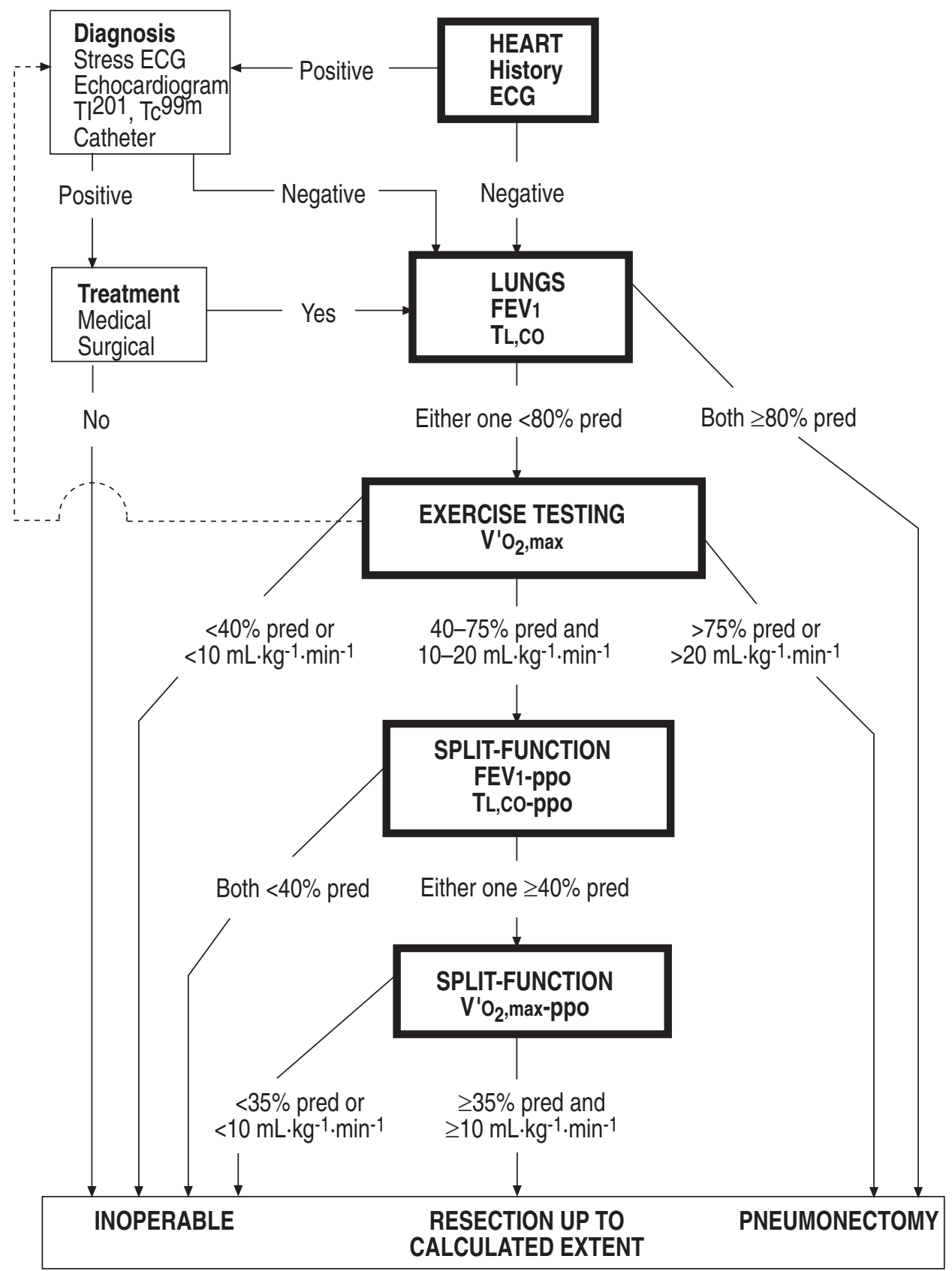

Fig. 1. - Algorithm for the assessment of the cardiorespiratory reserves (functional operability) of lung resection candidates. Patients undergo successive steps of functional investigation from top to bottom, until they qualify for varying extents of resection or are deemed inoperable. The "safety loop" for patients with cardiac problems is indicated in the upper left-hand corner; the cardiac work-up and treatment are only described qualitatively. The dashed line leading from exercise testing back to the cardiac work-up is for patients with a negative cardiac history and a normal ECG, who show symptoms or signs of ischaemia during exercise testing. TI: thallium; Tc: technetium; $V^{\prime} \mathrm{O}_{2}$,max: maximal oxygen uptake on exercise; ppo: predicted postoperative; ECG: electrocardiograph; FEV 1 : forced expiratory volume in one second; TL,CO: transfer factor of the lung for carbon monoxide.

functional postoperative reserves better than simple PFT, but has been investigated much less frequently than PFT [70, 124, 148, 149]. As early as 1965, DeGrAFF et al. [70] reported on exercise limitation after extensive pulmonary resection. CoRRIs et al. [124] analysed a group of 28 patients 4 months after pneumonectomy, and found that the average reduction was $22 \%$ for the FEV $1,29 \%$ for $\mathrm{VC}$, and $23 \%$ for $V^{\prime} \mathrm{O}_{2}$, max. VAN MIEGHEM and DemedTs [148] studied 28 patients (14 lobectomies and 14 pneumonectomies) 6 months after surgery, and found a decrease in VC of $15 \%$ after lobectomy and $37 \%$ after pneumonectomy, the values for FEV1 were 12 and $33 \%$, respectively, and for $V^{\prime} \mathrm{O}_{2}$, max 11 and $21 \%$, respectively.

In a recent report, Bolliger et al. [150] analysed patients 3 and 6 months postoperatively. Lobectomy led to an early functional deficit followed by later recovery, with little permanent loss in pulmonary function $(\leq 10 \%)$ and with no decrease in exercise capacity, whereas pneumonectomy led to an early permanent functional loss of about $33 \%$ in pulmonary function and $20 \%$ in exercise capacity. The findings of BoLLIGER et al. [150] 
are similar to those of van Mieghem and Demedts [148] for pneumonectomies, but show less permanent functional loss after lobectomy.

Pelletier et al. [149] investigated 20 patients after pneumonectomy and 27 after lobectomy. The mean decrease in FEV1 was $17 \%$ after lobectomy and $31 \%$ after pneumonectomy, and the respective values for the maximal work capacity were 12 and $26 \%$. As the analysis was performed early after surgery ( 2 months), it is more difficult to compare to other reports, and probably overestimates the permanent functional loss after lobectomy. A further interesting finding of this study was a weak relationship between the decrease in FEV1, and in exercise capacity $\left(r^{2}=0.30\right)$. Subjectively, pneumonectomy but not lobectomy led to an appreciable increase in dyspnoea during exercise.

The study by Bolliger et al. [150] came to similar conclusions about the patient-rated factors limiting exercise; before the operation, the majority of patients indicated leg muscle fatigue as the factor limiting their exercise capacity. Three and 6 months after surgery, however, leg muscle fatigue remained the most important subjective factor only in lobectomy patients, whereas after pneumonectomy dyspnoea became the leading cause. Objectively, pneumonectomy led to a significantly smaller breathing reserve and $\mathrm{Pa}, \mathrm{O}_{2}$ at peak exercise than lobectomy, which probably reflects a limited transfer capacity of the reduced alveolar surface. Most recently, NEZU et al. [151] reported similar results in a group of 82 patients.

There is consensus in the literature that resections not exceeding one lobe lead to very little permanent functional deficit, whereas pneumonectomies cause a permanent deficit which is bigger for pulmonary function than for exercise capacity.

\section{New expectations with lung volume reduction surgery?}

The treatment of end-stage pulmonary emphysema had been entirely medical until CoOPER et al. [152] reported very promising results after bilateral surgical volume reduction in a series of patients with severe COPD. This procedure had originally been introduced by BRANTIGAN and Mueller [153] in 1957, but was subsequently abandoned because of a high mortality rate. In the series of COOPER et al. [152], there was no mortality and the FEV1 improved by $82 \%$. The basic concept is to reduce hyperinflation through resection of poorly functioning lung parenchyma, which leads to a marked decrease in total lung capacity (TLC) and RV. These changes are associated with marked symptom relief, and improvement in exercise tolerance and quality of life. The field of lung volume reduction surgery (LVRS) is currently rapidly expanding but still needs validation over time [154].

The concept of removing lung parenchyma to improve pulmonary function is, of course, almost contrary to what has been traditional in the surgical treatment of high-risk lung resection candidates, where the minimal amount of tissue is removed to achieve curative resection. This should rarely be less than a lobectomy, as lesser resections are fraught with a clearly higher local tumour recurrence rate [155]. The thought of combin- ing LVRS with tumour resection in functionally inoperable lung cancer patients is, therefore, understandably attractive. First reports on successful operations in highly selected patients have appeared in a letter from GoNZALEZ MunOz et al. [156], who reported on an emphysematous patient with a carcinomatous nodule of the left upper lobe. The patient had severely impaired pulmonary function with an FEV1 of $660 \mathrm{~mL}(21 \%$ pred) and a TL,CO of $37 \%$ pred. A wedge resection of the nodule combined with volume reduction of about $20 \%$ of the lower lobe was performed with an uneventful postoperative course, the FEV1 being $696 \mathrm{~mL}$ (22\% pred) at 2 weeks. Another three emphysematous patients, with FEV1 values of 29, 30 and $33 \%$ pred, respectively, were reported by COOPER et al. [157]. These patients underwent median sternotomy, formal lobectomy and LVRS. Their postoperative FEV1 was 44, 44 and $48 \%$ pred, respectively.

These early reports are promising indeed. Long-term follow-up, however, will determine whether the thresholds of functional operability can be further lowered in such highly selected patients. In a recent editorial, OLSEN [158] speculated that eventually almost no one might be considered inoperable for pulmonary reasons. One caveat remains: enthusiasm over the technical feasibility should not lead surgeons to perform minimal resections in high-risk lung cancer patients, jeopardizing their chance of a curative resection [155].

\section{Summary}

Over the last $40 \mathrm{yrs}$, many single and combined parameters of functional operability for pulmonary resection have been proposed and reviewed regularly [38, 40, 45, 159-163]. Despite tremendous advances in operative techniques and perioperative care, surgical morbidity and mortality after pulmonary resections remain relatively high. An overall mortality of $\pm 5 \%$ has to be termed good. So far, no ideal single parameter for the assessment of functional operability in lung resection candidates has been found. PFTs adequately assess the pulmonary risk, and baseline or stress ECG, echocardiography and nuclear cardiac studies assess the cardiac risk. The increasing use of exercise testing with simultaneous measurement of pulmonary and cardiovascular parameters is a clear step towards this "ideal" parameter.

The recent development in the functional evaluation before pulmonary resection emphasizes the importance of the predicted postoperative function. This is possible with pulmonary perfusion scans and has been shown to be quite accurate by many authors [34, 48, 115-117, $124,125]$. Surprisingly, the same simple formula can be used to predict not only the postoperative FEV1, but also the $T \mathrm{~L}, \mathrm{CO}[34,47,48]$ and, most recently, the $V^{\prime} \mathrm{O}_{2}$, $\max$ $[48,124,125]$. The calculated ppo-values take the extent of resection into account, which permits good individual risk assessment.

Apart from the split-function studies, the trend of the last decade seems to favour exercise testing with the measurement of $V^{\prime} \mathrm{O}_{2}$,max. The majority of reports found $V^{\prime} \mathrm{O}_{2}$, max a good independent risk predictor. Maximal exercise tests are fairly easy to standardize, and, in our opinion, $V^{\prime} \mathrm{O}_{2}$, max represents the single best parameter to 
evaluate both the pulmonary as well as the cardiovascular reserves.

A further trend lies in the increasing use of percentage of predicted normal rather than absolute values mainly for the FEV1 [34, 43, 45] and TL,CO [34, 47] but, most recently, also for $V^{\prime} \mathrm{O}_{2}$, max $[59,60]$. This trend has the advantage of taking age, sex and height into consideration. This notion will probably gain importance, especially with the current massive increase in lung cancer in females. Many established criteria of operability have been proposed following studies conducted in United States veterans administration institutions, where the patients were almost exclusively male [28]. Furthermore, the majority of lung resection candidates in industrialized nations suffer from lung cancer, a disease with a mortality approaching $100 \%$ when not treated surgically. In these patients, postoperative complications can, therefore, almost always be accepted unless they are fatal.

In analysing the literature, it is therefore important to differentiate between morbidity and mortality. Only parameters which have consistently been shown to indicate the latter, e.g. a $V^{\prime} \mathrm{O}_{2}$, max $<10 \mathrm{~mL} \cdot \mathrm{kg}^{-1} \cdot \mathrm{min}^{-1}$, are prohibitive for surgery. The recent emergence of minimally invasive procedures in the field of thoracic surgery may well help to decrease perioperative mortality [164] and allow surgical resection in patients who, so far, would have been deemed functionally inoperable. Finally, the combination of lung cancer surgery with lung volume reduction is an attractive concept in selected patients who would otherwise be deemed functionally inoperable by any existing test.

Patients with normal or only slightly impaired pulmonary function (forced expiratory volume in one second and transfer factor of the lung for carbon dioxide $\geq 80 \%$ pred) and no cardiovascular risk factors tolerate pulmonary resections up to a pneumonectomy without any problems. Resections involving not more than one lobe usually lead to an early functional deficit followed by later recovery. Their permanent functional loss in pulmonary function is small $(\leq 10 \%)$ and their exercise capacity is only slightly reduced, or not at all. Pneumonectomy, on the other hand, leads to an early permanent loss of about $33 \%$ in pulmonary function and $20 \%$ in exercise capacity $[148,150]$. Thus, pulmonary function tests alone overestimate the functional loss after lung resection. Knowledge of these changes depending on the extent of resection is useful for the preoperative counselling, including the estimation of a patient's postoperative working capacity.

\section{References}

1. Belani CP. Multimodality management of regionally advanced non-small-cell lung cancer. Semin Oncol 1993; 20: 302-314.

2. Ruckdeschel JC. Therapeutic options for the treatment of small cell and non-small cell lung cancer. Cur Opin Oncol 1993; 5: 323-334.

3. Bechard DE. Pulmonary function testing. In: LoCicero J III, ed. Diagnostic Procedures For Thoracic Diseases. Chest Surgery Clinics. Philadelphia, W.B. Saunders Co; 1992; 565-586.

4. Eugene J, Brown SE, Light RW, Milne NE, Stemmer EA. Maximum oxygen consumption: a physiologic guide to pulmonary resection. Surg Forum 1982; 33: 260-262.

5. Gaensler EA, Patton WE, Frank NR. Bronchospirometry. VII. Indications. J Lab Clin Med 1953; 41: 456-477.

6. Gaensler EA, Cugell DW, Lindgren I, Verstraeten JM, Smith SS, Strieder JW. The role of pulmonary insufficiency in mortality and invalidism following surgery for pulmonary tuberculosis. J Thorac Cardiovasc Surg 1955; 29: 163-187.

7. Bühlmann AA, Rossier PH. Die Bedeutung der Lungenfunktionsprüfung für die Thoraxchirurgie. Dtsch Med Wschr 1960; 85: 621-625.

8. Laros CD. Preoperative function analysis: possibilities and limits. Pneumologie 1972; 147: 83-94.

9. Uggla L-G. Indications for and results of thoracic surgery with regard to respiratory and circulatory function tests. Acta Chir Scand 1956; 111: 196-212.

10. Bryant LR, Rams JJ, Trinkle JK, Malette WG. Presentday risk of thoracotomy in patients with compromised pulmonary function. Arch Surg 1970; 101: 140-144.

11. Baker RR. The clinical management of bronchogenic carcinoma - a progress report. Johns Hopkins Med J 1975; 137: 208-215.

12. Peters RM, Clausen JL,Tisi GM. Extending resectability for carcinoma of the lung in patients with impaired pulmonary function. Ann Thorac Surg 1978; 26: 250-260.

13. Perruchoud A, Meili U, Kopp C, Graedel E, Hasse J, Herzog H. Präoperative Abklärung der Lungenfunktion bei Patienten mit Bronchialkarzinom. Schweiz MedWschr 1979; 109: 832-835.

14. Boushy SF, Billig DM, North LB, Helgason AH. Clinical course related to preoperative and postoperative pulmonary function in patients with bronchogenic carcinoma. Chest 1971; 59: 383-391.

15. Wernly JA, DeMeester TR, Kirchner PT, Myerowitz PD, Oxford DE, Golomb HM. Clinical value of quantitative ventilation-perfusion lung scans in the surgical management of bronchogenic carcinoma. $J$ Thorac Cardiovasc Surg 1980; 80: 535-543.

16. Loddenkemper R, Gabler A, Göbel D. Criteria of functional operability in patients with bronchial carcinoma: preoperative assessment of risk and prediction of postoperative function. Thorac Cardiovasc Surg 1983; 31: 334-337.

17. Miller JI. Physiologic evaluation of pulmonary function in the candidate for lung resection. J Thorac Cardiovasc Surg 1993; 105: 347-352.

18. Mittman C. Assessment of operative risk in thoracic surgery. Am Rev Respir Dis 1961; 84: 197-207.

19. Nagasaki F, Flehinger BJ, Martini N. Complications of surgery in the treatment of carcinoma of the lung. Chest 1982; 82: 25-29.

20. Pate P, Tenholder MF, Griffin JP, Eastridge CE, Weiman DS. Preoperative assessment of the high risk patient for lung resection. Ann Thorac Surg 1996; 61: 1494-1500.

21. Gerson G. Preoperative respiratory function tests and postoperative mortality: a study of patients undergoing surgery for carcinoma of the bronchus. Br J Anaesth 1969; 41: 967-971.

22. Lockwood P. An improved risk prediction method in bronchial carcinoma surgery. Respiration 1980; 39: 166-171.

23. Schaefer P, Meyer-Erkelenz J-D, Effert S. Lungenfunktion und Operabilität. Dtsch Med Wschr 1978; 103: 123129. 
24. Bagg LR, Evans SJW, Empey DW, Hughes DTD. Analysis of simple pulmonary function screening tests in preoperative assessment before lung resection for bronchogenic carcinoma. Respiration 1981; 42: 1-7.

25. Grabow L, Wassner UJ. Zur Frage der Zuverlässigkeit von präoperativen Vorhersagen für die postoperativ verbleibende Lungenfunktion. Beitr Klin Tuberk 1963; 127: 592-604.

26. Nolte D. Aussagewert von Funktionsdaten für Indikation und Kontraindikation in der Lungenchirurgie. Thoraxchirurgie 1973; 21: 263-269.

27. Lockwood P. Lung function test results and the risk of post-thoracotomy complications. Respiration 1973; 30: 529-542.

28. Olsen GN, Block AJ, Swenson EW, Castle JR, Wynne JW. Pulmonary function evaluation of the lung resection candidate: a prospective study. Am Rev Respir Dis 1975; 111: 379-387.

29. Bachofen H, Bühlmann AA, Scherrer M. Präoperative Lungenfunktionsdiagnostik. In: Praktische Lungenfunktionsprüfung. Stuttgart, Thieme, 1978; 141-145.

30. Meyer-Erkelenz JD, Sieverts H, Mösges R. Lungenfunktionsdiagnostik in Ruhe-Bezugswerte. Prax Pneumol 1980; 34: 76-89.

31. Meyer-Erkelenz JD, Mösges R, Sieverts H. Spiroergometrie (kardio-pulmonale Funktion unter Belastung). Prax Pneumol 1980; 34: 585-600.

32. Cander L. Physiologic assessment and management of the preoperative patient with pulmonary emphysema. Am J Cardiol 1963; 12: 324-326.

33. Ferguson MK, Little L, Rizzo L, et al. Diffusing capacity predicts morbidity and mortality after pulmonary resection. J Thorac Cardiovasc Surg 1988; 96: 894-900.

34. Markos J, Mullan BP, Hillman DR, et al. Preoperative assessment as a predictor of mortality and morbidity after lung resection. Am Rev Respir Dis 1989; 139: 902-910.

35. Mittman C, Bruderman I. Lung cancer: to operate or not? Am Rev Respir Dis 1977; 116: 477-496.

36. Karliner JS, Williams MH. Relationship between preoperative pulmonary function studies and prognosis of patients undergoing pneumonectomy for carcinoma of the lung. Dis Chest 1968; 54: 112-118.

37. Lebram C, Buhlmann AA. Zur Letalität und Häufigkeit schwerer respiratorischer Störungen nach thoraxchirurgischen Eingriffen bei eingeschränkter Lungenfunktion. Schweiz Med Wschr 1968; 98: 444-449.

38. Tisi GM. Preoperative evaluation of pulmonary function. Am Rev Respir Dis 1979; 119: 293-310.

39. Morice RC, Peters EJ, Ryan MB, Putnam JB, Ali MK, Roth JA. Exercise testing in the evaluation of patients at high risk for complications from lung resection. Chest 1992; 101: 356-361.

40. American College of Chest Physicians. Preoperative pulmonary function testing. Ann Intern Med 1990; 112: 793-794.

41. Kearney DJ, Lee TH, Reilly JJ, DeCamp MM, Sugarbaker DJ. Assessment of operative risk in patients undergoing lung resection: importance of predicted pulmonary function. Chest 1994; 105: 753-759.

42. Bolliger CT, Soler M, Stulz P, et al. Evaluation of high risk lung resection candidates: pulmonary haemodynamics versus exercise testing. Respiration 1994; 61: 181-186.

43. Nakahara K, Miyoshi S, Nakagawa K. A method for predicting postoperative lung function and its relation to postoperative complications in patients with lung cancer. Ann Thorac Surg 1992; 54: 1016-1017.
44. Kristersson S, Lindell S-E, Svanberg L. Prediction of pulmonary function loss due to pneumonectomy using ${ }^{133}$ Xe-radiospirometry. Chest 1972; 62: 694-698.

45. Gass GD, Olsen GN. Preoperative pulmonary function testing to predict postoperative morbidity and mortality. Chest 1986; 89: 127-135.

46. Holden DA, Rice TW, Stelmach K, Meeker DP. Exercise testing, 6 min walk and stair climb in the evaluation of patients at high risk of pulmonary resection. Chest 1992; 102: 1774-1779.

47. Pierce RJ, Copland JM, Sharpe K, Barter CE. Preoperative risk evaluation for lung cancer resection: predicted postoperative product as a predictor of surgical mortality. Am Rev Respir Dis 1994; 150: 947-955.

48. Bolliger CT, Wyser C, Roser H, Solar M, Perruchoud AP. Lung scanning and exercise testing for the prediction of postoperative performance in lung resection candidates at increased risk for complications. Chest 1995; 108: 341-348.

49. Didolkar MS, Moore RH, Takita H. Evaluation of the risk in pulmonary resection for bronchogenic carcinoma. Am J Surg 1974; 127: 700-703.

50. Goldman L, Caldera DL, Nussbaum SR, et al. Multifactorial index of cardiac risk in noncardiac surgical procedures. N Engl J Med 1977; 297: 845-850.

51. Van Nostrand D, Kjelsberg MO, Humphrey EW. Preresectional evaluation of risk from pneumonectomy. Surg Gynecol Obstet 1968; 127: 306-312.

52. Carliner NH, Fisher ML, Plotnik GD, et al. The preoperative electrocardiogram as an indicator of risk in major noncardiac surgery. Can J Cardiol 1986; 2: 134-137.

53. Raby KE, Goldman L, Creager MA, et al. Correlation between preoperative ischemia and major cardiac events after peripheral vascular surgery. N Engl J Med 1989; 321: 1296-1300.

54. Goerg R, Dimbeck H, Daum S. Routinemässige Rechtsherzkatheterisation vor jeder Lungenresektion? Prax Klin Pneumol 1983; 37: 816-818.

55. Keller R, Kopp C, Zutter W, Mlczoch J, Herzog H. Der Lungenkreislauf als leistungsbegrenzender Faktor bei Patienten. Pneumonologie 1976; Suppl.: S27-S39.

56. Fee HJ, Holmes EC, Gewirtz HS, Ramming KP, Alexander $\mathrm{JM}$. Role of pulmonary vascular resistance measurements in preoperative evaluation of candidates for pulmonary resection. J Thorac Cardiovasc Surg 1978; 75: 519524.

57. Smith TP, Kinasewitz GT, Tucker WY, Spillers WP, George RB. Exercise capacity as a predictor of post-thoracotomy morbidity. Am Rev Respir Dis 1984; 129: 730-734.

58. Bechard D, Wetstein L. Assessment of exercise oxygen consumption as preoperative criterion for lung resection. Ann Thorac Surg 1987; 44: 344-349.

59. Bolliger CT, Jordan P, Soler M, et al. Exercise capacity as a predictor of postoperative complications in lung resection candidates. Am J Respir Crti Care Med 1995; 151: 1472-1480.

60. Morice RC, Walsh GL, Ali MK, Roth JA. Redefining the lowest exercise peak oxygen consumption acceptable for lung resection of high risk patients. Chest 1996; 110: $161 \mathrm{~S}$.

61. Bolton JWR, Weiman DS, Haynes JL, Hornung CA, Olsen GN, Almond CH. Stair-climbing as an indicator of pulmonary function. Chest 1987; 92: 783-787.

62. Olsen GN, Bolton JWR, Weiman DS, Hornung CA. Stair-climbing as an exercise test to predict the postoperative complications of lung resection. Chest 1991; 99: 587-590. 
63. Krosnick A, Wasserman F. Cardiac arrhythmias in the older age group following thoracic surgery. Am J Med Sci 1955; 230: 541-550.

64. Bates M. Results of surgery for bronchial carcinoma in patients aged 70 and over. Thorax 1970; 25: 77-78.

65. Kirsh MM, Rotman H, Bove E, et al. Major pulmonary resection for bronchogenic carcinoma in the elderly. Ann Thorac Surg 1976; 22: 369-373.

66. Breyer RH, Zippe C, Pharr WF, Jensik RJ, Kittle CF, Faber LP. Thoracotomy in patients over age seventy years. J Thorac Cardiovasc Surg 1981; 81: 187-193.

67. Berggren H, Ekroth R, Malmberg R, Naucler J,WilliamOlsson G. Hospital mortality and long-term survival in relation to preoperative function in elderly patients with bronchogenic carcinoma. Ann Thorac Surg 1984; 38: 633-636.

68. Gerson MC, Hurst JM, Hertzberg VS, et al. Cardiac prognosis in noncardiac geriatric surgery. Ann Intern Med 1985; 103: 832-837.

69. Damhuis RAM, Schütte PR. Resection rates and postoperative mortality in 7,899 patients with lung cancer. Eur Respir J 1996; 9: 7-10.

70. DeGraff AC Jr, Taylor HF, Ord JW, Chuang TH, Johnson RL Jr. Exercise limitation following extensive pulmonary resection. J Clin Invest 1965; 44: 1514-1522.

71. Sloan H, Morris JD, Figley M, Lee R. Temporary unilateral occlusion of the pulmonary artery in the preoperative evaluation of thoracic patients. $J$ Thorac Surg 1955; 30: 591-597.

72. Taube K, Konietzko N. Prediction of postoperative cardiopulmonaryfunction in patients undergoing pneumonectomy. Thorac Cardiovasc Surg 1980; 28: 348-351.

73. Olsen GN, Weiman DS, Bolton JWR, et al. Submaximal invasive exercise testing and quantitative lung scanning in the evaluation for tolerance of lung resection. Chest 1989; 95: 267-273.

74. Bründler H, Chen S, Perruchoud AP. Right heart catheterization in the pre-operative evaluation of patients with lung cancer. Respiration 1985; 48: 261-268.

75. Ueda S, Tanita T, Ono S, Koike K, Fujimura S. Changes in right ventricular end-diastolic volume index by unilateral pulmonary arterial occlusion test: prediction for postoperative cardiac complications in lung resection. Am Rev Respir Dis 1993; 149: A738.

76. Lewis JW, Bastanfar M, Gabriel F, Mascha E. Right heart function and prediction of respiratory morbidity in patients undergoing pneumonectomy with moderately severe cardiopulmonary dysfunction. $J$ Thorac Cardiovasc Surg 1994; 108: 169-175.

77. Tarhan S, Moffitt E, Taylor WF, Giuliani ER. Myocardial infarction after general anesthesia. J Am Med Assoc 1972; 220: 1451-1454.

78. Carliner NH, Fisher ML, Plotnick GD, et al. Routine preoperative exercise testing in patients undergoing major noncardiac surgery. Am J Cardiol 1985; 56: $51-58$.

79. von Knorring J. Postoperative myocardial infarction: a prospective study in a risk group of surgical patients. Surgery 1981; 90: 55-60.

80. Goldman L. Cardiac risk and complications of noncardiac surgery. Ann Intern Med 1983; 98: 504-513.

81. Fegert G, Hollenberg M, Browner W, et al. Perioperative myocardial ischemia in the noncardiac surgical patient. Anesthesiology 1988; 69: A49.

82. Skarvan K. Das Herz im Spannungsfeld zwischen Operation und Anästhesie. Schweiz Rundsch Med Prax 1989; 78: $1427-1433$.
83. Mangano DT. Perioperative cardiac morbidity. Anesthesiology 1990; 72: 153-184.

84. Baron J-F, Mundler O, Bertrand M, et al. Diprydamolethallium scintigraphy and gated radionuclide angiography to assess cardiac risk before abdominal aortic surgery. N Engl J Med 1994; 330: 663-669.

85. Adams JE, Sicard GA, Allen BT, et al. Diagnosis of perioperative myocardial infarction with measurement of cardiac troponin I. N Engl J Med 1994; 330: 670-674.

86. Goldman L. Assessment of perioperative cardiac risk. N Engl J Med 1994; 330: 707-709.

87. Steen PA, Tinker JH, Tarhan S. Myocardial reinfarction after anesthesia and surgery. J Am Med Assoc 1978; 239: 2566-2570.

88. Foster ED, Davis KB, Carpenter JA, Abele S, Fray D. Risk of noncardiac operation in patients with defined coronary disease: the coronary artery surgery study (CASS) registry experience. Ann Thorac Surg 1986; 41: 42-50.

89. Bailey CC, Betts RH. Cardiac arrhythmias following pneumonectomy. N Engl J Med 1943; 229: 356-359.

90. Currens JH, White PD, Churchill ED. Cardiac arrhythmias following thoracic surgery. N Engl J Med 1943; 229: 360-364.

91. Cerney CI. The prophylaxis of cardiac arrhythmias complicating pulmonary surgery. J Thorac Surg 1957; 34: $105-110$.

92. Harpole DH, Liptay MJ, DeCamp MM, Mentzer SJ, Swanson SJ, Sugarbaker DJ. Prospective analysis of pneumonectomy: risk factors for major morbidity and cardiac dysrhythmias. Ann Thorac Surg 1996; 61: 977-982.

93. Amar D, Burt M, Reinsel RA, Leung DHY. Relationship of early postoperative dysrhythmias and long-term outcome after resection of non-small cell lung cancer. Chest 1996; 110: 437-439.

94. Wheat WM, Burford TB. Digitalis in surgery: extension of classical indications. J Thorac Cardiovasc Surg 1961; 41: 162-168.

95. Shields TN, Ujiki GT. Digitalisation for prevention of arrhythmias following pulmonary surgery. Surg Gynecol Obstet 1968; 126: 743-746.

96. Burman SO. The prophylactic use of digitalis before thoracotomy. Ann Thorac Surg 1972; 14: 359-368.

97. Ritchie AJ, Danton M, Gibbons JRP. Prophylactic digitalisation in pulmonary surgery. Thorax 1992; 47: 41-43.

98. Moghissi K, Connolly CK. Resection rates in lung cancer patients. Eur Respir J 1996; 9: 5-6.

99. Loddenkemper R. Funktionelle Operabilität beim Bronchialkarzinom. Prospektive Studie zur Einschätzung des Operationsrisikos und der postoperativenLungenfunktion. Freie Universität Berlin, Habil.-Schrift, 1983. (Unpublished).

100. Hasse J. Surgical Treatment of Bronchial Carcinoma. Berlin Heidelberg, Springer-Verlag, 1986.

101. Jacobaeus HC, Frenckner P, Björkman S. Some attempts at determining the volume and function of each lung separately. Acta Med Scand 1932; 79: 174-215.

102. Carlens E. A new flexible double-lumen catheter for bronchospirometry. J Thorac Surg 1949; 18: 742-746.

103. Laros CD, Swierenga J. Bronchospirometry in bronchial carcinoma. Scand J Respir Dis 1967; 47: 256-261.

104. Ranson-Bitker B, Aidan DS, Le Roy Ladurie M. Signification de la répartition de la consommation d'oxygène et de la ventilation avant chirurgie thoracique. Bull Physiopath Respir 1970; 6: 687-699.

105. Neuhaus H,Cherniack NS. A bronchospirometric method of estimating the effect of pneumonectomy on the 
maximum breathing capacity. $J$ Thorac Cardiovasc Surg 1968; 55: 144-148.

106. Anzueto A, Levine SM, Tillis WP, Calhoon JH, Bryan CL. Use of the flow-volume loop in the diagnosis of bronchial stenosis after single-lung transplantaiton. Chest 1994; 105: 934-936.

107. Fabel H. Funktionsstörungen des Lungenkreislaufs und des Gasaustauschs und ihre Bedeutung für die Lungenresektion. Thoraxchirurgie 1973; 21: 258-262.

108. Bergan F. A simple method for determination of the relative function of the right and left lung. Acta Chir Scand 1960; 253: S58-S63.

109. DeMeester TR, Van Heertum RL, Karas JR. Preoperative evaluation with different pulmonary function. Ann Thorac Surg 1974; 18: 61-71.

110. Marion JM, Alderson PO, Lefrak SS, Senior RM, Jacobs MH. Unilateral lung function: comparison of the lateral position test with radionuclide ventilation-perfusion studies. Chest 1976; 69: 5-9.

111. Jay SJ, Stonehill RB, Kiblawi SO, Norton J. Variability of the lateral position test in normal subjects. Am Rev Respir Dis 1980; 121: 165-168.

112. Knipping HW, Bolt W, Valentin H, Venrath H, Endler P. Eine neue Methode zur Prüfung der Herz-und Lungenfunktion. Dtsch Med Wschr 1955; 80: 1146-1147.

113. Kristersson S, Arborelius M Jr, Jungquist G, Lilja B, Svanbverg L. Prediction of ventilatory capacity after lobectomy. Scand J Respir Dis 1973; 54: 315-325.

114. Tønnesen KH, Dige-Petersen H, Lund JO. Lung split function test and pneumonectomy. Scand J Thorac Cardiovasc Surg 1978; 12: 133-136.

115. Ali MK, Mountain CF, Ewer MS, Johnston D, Haynie TP. Predicting loss of pulmonary function after pulmonary resection for bronchogenic carcinoma. Chest 1980; 77: 337-342.

116. Olsen GN, Block AJ, Tobias JA. Prediction of postpneumonectomy pulmonary function using quantitative macroaggregate lung scanning. Chest 1974; 66: 13-16.

117. Boysen PG, Harris JO, Block AJ, Olsen GN. Prospective evaluation for pneumonectomy using perfusion scanning. Follow-up beyond one year. Chest 1981; 80: 163-166.

118. Ellis DA, Hawkins T, Gibson GJ, Nariman S. Role of lung scanning in assessing the resectability of bronchial carcinoma. Thorax 1983; 38: 261-266.

119. Ladurie ML, Ranson-Bitker B. Uncertainties in the expected value for forced expiratory volume in one second after surgery. Chest 1986; 90: 222-228.

120. Segal JJ, Butterworth BA. Ventilatory capacity in chronic bronchitis in relation to carbon dioxide retention. Scand J Respir Dis 1966; 47: 215-224.

121. Zeiher BG, Gross TJ, Kern JA, Lanza LA, Peterson MW. Predicting postoperative pulmonary function in patients undergoing lung resection. Chest 1995; 108: $68-72$.

122. Nakahara K, Monden Y, Ohno K, Miyoshi S, Maeda H, Kawashima Y. A method for predicting postoperative lung function and its relation to postoperative complications in patients with lung cancer. Ann Thorac Surg 1985; 39: 260-265.

123. Wu MT, Chang JM, Chiang AA, et al. Use of quantitative $\mathrm{CT}$ to predict postoperative lung function in patients with lung cancer. Radiology 1994; 191: 257-262.

124. Corris PA, Ellis DA, Hawkins T, Gibson GJ. Use of radionuclide scanning in the preoperative estimation of pulmonary function after pneumonectomy. Thorax 1987; 42: 285-291.

125. Puente-Maestu L, De Lucas P, Arnedillo A, Calle M,
Tatai E, Monturiol M. Prediction of maximal oxygen uptake after thoracic surgery by radionuclide perfusion scanning. Am Rev Respir Dis 1994; 149: A785.

126. Bagg LR. The 12 min walking distance; its use in the preoperative assessment of patients with bronchial carcinoma before lung resection. Respiration 1984; 46: 342-345.

127. Pollock M, Roa J, Benditt J, Celli B. Estimation of ventilatory reserve by stair climbing. A study in patients with chronic airflow obstruction. Chest 1993; 104: 1378-1383.

128. Older P, Smith R, Courtney P, Hone R. Preoperative evaluation of cardiac failure and ischemia in elderly patients by cardiopulmonary exercise testing. Chest 1993; 104: 701-704.

129. Miyoshi S, Nakahara K, Ohno K, Monden Y, Kawashima Y. Exercise tolerance test in lung cancer patients: the relationship between exercise capacity and post-thoracotomy hospital mortality. Ann Thorac Surg 1987; 44: 487-490.

130. Nakagawa K, Nakahara K, Miyoshi S, Kawashima Y. Oxygen transport during incremental exercise load as a predictor of operative risk in lung cancer patients. Chest 1992; 101: 1369-1375.

131. Pierce RJ, Pretto JJ, Rochford PD, Barter CE. Lobar occlusion in the preoperative assessment of patients with lung cancer. Br J Dis Chest 1986; 80: 27-36.

132. Rao V, Todd TRJ, Kuus A, Buth KJ, Pearson FG. Exercise oximetry versus spirometry in the assessment of risk prior to lung resection. Ann Thorac Surg 1995; 60: 603-609.

133. Taylor HL, Buskirk E, Henschel A. Maximal oxygen intake as an objective measurement of cardiorespiratory performance. J Appl Physiol 1955; 8: 73-80.

134. Froelicher VF, Brammell H, Davis G, Noguera I, Stewart A, Lancaster MC. A comparison of three maximal treadmill exercise protocols. J Appl Physiol 1974; 36: 720-725.

135. Kappler J, Ziesche S, Nelson J, Francis GS. The reproducibility of hemodynamic and gas exchange data during exercise in patients with stable congestive heart failure. Heart Failure 1986; 2: 157-163.

136. Janicki JS, Gupta S, Ferris ST, McElroy PA. Long-term reproducibility of respiratory gas exchange measurements during exercise in patients with stable cardiac failure. Chest 1990; 97: 12-17.

137. Cahalin LP, Mathier MA, Semigran MJ, Dec GW, DiSalvo TG. The six minute walk test predicts peak oxygen uptake and survival in patients with advanced heart failure. Chest 1996; 110: 325-332.

138. Colman NC, Schraufnagel DE, Rivington RN, Pardy RL. Exercise testing in evaluation of patients for lung resection. Am Rev Respir Dis 1982; 125: 604-606.

139. Olsen GN. Preoperative physiology and lung resection: Scan? Exercise? Both? Chest 1992; 101: 300-301.

140. Dales RE, Dionne G, Leech JA, Lunau M, Schweitzer I. Preoperative prediction of pulmonary complications following thoracic surgery. Chest 1993; 104: 155-159.

141. Epstein SK, Faling LJ, Daly BDT, Celli BR. Predicting complications after pulmonary resection: preoperative exercise testing $v s$ a multifactorial cardiopulmonary risk index. Chest 1993; 104: 694-700.

142. Epstein SK, Faling LJ, Daly BDT, Celli BR. Inability to perform bicycle ergometry predicts increased morbidity and mortality after lung resection. Chest 1995; 107: $311-316$.

143. Wyser C, Stulz P, Solèr M, et al. A prospective evaluation of an algorithm for the functional assessment of 
lung resection candidates. Am J Respir Crit Care Med 1997; 155: A146.

144. Hall DR. Regional lung function after pneumonectomy. Thorax 1974; 29: 425-431.

145. Legge JS, Palmer KNV. Effect of lung resection for bronchial carcinoma on pulmonary function in patients with and without chronic bronchitis. Thorax 1975; 30: 563-565.

146. Berend N,Woolcock AJ, Marlin GE. Effects of lobectomy on lung function. Thorax 1980; 35: 145-150.

147. Veneskoski T, Sovijärvi ARA, Muittari A. Effect of lung resection on regional lung function assessed by ${ }^{133}$ Xe-radiospirometry. Lung 1982; 160: 45-55.

148. Van Mieghem W, Demedts M. Cardiopulmonary function after lobectomy or pneumonectomy for pulmonary neoplasm. Respir Med 1989; 83: 199-206.

149. Pelletier C, Lapointe L, LeBlanc P. Effects of lung resection on pulmonary function and exercise capacity. Thorax 1990; 45: 497-502.

150. Bolliger CT, Jordan $\mathrm{P}$, Solèr $\mathrm{M}$, et al. Pulmonary function and exercise capacity after lung resection. Eur Respir $J$ 1996; 97: 415-421.

151. Nezu K, Kushibe K, Tojo T, Kitamura S. Exercise capacity after lung resection for lung cancer. Chest 1996; 110: 161S

152. Cooper JD, Trulock EP, Triantafillou AN, et al. Bilateral pneumectomy (volume reduction) for chronic obstructive pulmonary disease. J Thorac Cardiovasc Surg 1995; 109: 106-119.

153. Brantigan OC, Mueller E. Surgical treatment of pulmonary emphysema. Am Surg 1957; 23: 789-804.
154. Davies L, Calverley PMA. Lung volume reduction surgery in chronic obstructive pulmonary disease. Thorax 1996; 51 (Suppl. 2): s29-s34.

155. Martini N, Bains MS, Burt ME, et al. Incidence of local recurrence and second primary tumors in resected stage I lung cancer. J Thorac Cardiovasc Surg 1995; 109: 120-129.

156. Gonzalez Munoz JI, Cordoba Pelaez M, Ferreiro Alvarez MJ, Ussetti Gil P,Varela de Ugarte A. Lung volume reduction surgery: new expectations in the surgical treatment of lung cancer. Chest 1996; 1664: 109.

157. Cooper JD, Patterson GA, DeMeester SR, Yusen RD, Lefrak SS. Lobectomy combined with lung volume reduction for high risk lung cancer patients with severe emphysema. Chest 1996; 110: 49S.

158. Olsen GN. Lung cancer resection: Who's inoperable? Chest 1995; 108: 298-299.

159. Reichel J. Assessment of operative risk of pneumonectomy. Chest 1972; 62: 570-576.

160. Olsen GN. The evolving role of exercise testing prior to lung resection. Chest 1989; 95: 218-225.

161. Zibrak JD, O'Donnell CR, Marton K. Indications for pulmonary function testing. Ann Intern Med 1990; 112: 763-771.

162. Wasserman K. Preoperative evaluation of cardiovascular reserve in the elderly. Chest 1993; 104: 663-664.

163. Reilly JJ, Mentzer SJ, Sugarbaker DJ. Preoperative assessment of patients undergoing pulmonary resection. Chest 1993; 103: 342S-345S.

164. Jaklitsch MT, Harpole DH, DeCamp MM, et al. Videoassisted thoracic surgery reduces expected operative mortality in the elderly. Am Rev Respir Dis 1994; 149: A510. 